\title{
CUSTOM-SIZED AORTIC VALVE: 3-DIMENSIONAL PRINTING USING GEOMETRIC MODELING OF AORTIC ROOT MORPHOLOGY
}

\author{
ÖZEL BOYUTLU AORT KAPAK: AORT KÖKÜ MORFOLOJISININ \\ GEOMETRIK MODELLEMESI KULLANARAK ÜÇ BOYUTLU BASKI
}

\author{
Nilgün BOZBUĞA ${ }^{1}$ (D) Ferhat TAŞ $^{2}$ (D) \\ ${ }^{1}$ Istanbul University, Istanbul Faculty of Medicine, Department of Surgical Medical Sciences, Department of Cardiovascular Surgery, Istanbul, Turkey \\ ${ }^{2}$ Istanbul University, Faculty of Science, Department of Mathematics, Geometry Division, Istanbul, Turkey
}

ORCID ID: N.B. 0000-0002-4401-5250; F.T. 0000-0001-5903-2881

Citation/Atff: Bozbuga N, Tas F. Custom-sized aortic valve: 3-dimensional printing using geometric modeling of aortic root morphology. Sağlık Bilimlerinde ileri Araştrmalar Dergisi 2022;5(1):1-5. https://doi.org/10.26650/JARHS2022-1041198

\section{ABSTRACT}

Objective: The aortic valve complex is an anatomical and a physiological junctional structure. Its root morphology presents a complex junctional structure extending from the ventriculoarterial to sinotubular junction and consisting of three Valsalva sinuses and cusps to achieve an optimal physiological pump function of the left ventricle. In this research study, a geometric model of the aortic complex was created allowing input to make it applicable in cardiac surgery.

Material and Methods: The aortic valve has a consistent shape that can be described mathematically, dependent on the root diameter. The geometric model of the mathematical structures was developed with the Bézier technique, that is, by obtaining a curve or surface that can be controlled by the designer. Primarily, the boundary Bézier curves of the aortic valve tissue to be modeled were determined, which then revealed a frame of the surface. In the next step, within this frame, aortic leaflets were obtained by interpolations.

Results: After the threedimensional (3-D) computer-aided design display was finished in Blender, the aortic valve complex was exported as a stereolithographic document and a model of the aortic root was printed using polylactic corrosive fibers.

Conclusion: Geometric modeling of heart valves obtained by threedimensional imaging can be used in the production of customized prosthetic valves. Evaluation of the anatomical structure features of the heart valves using geometrical modeling could be developed and adapted for other heart valves.

Keywords: Aortic valve, aortic root, geometric modeling, threedimensional printing

\section{öz}

Amaç: Aort kök morfolojisi, Valsalva sinüsleriyle aortik küspisler olmak üzere ventriküloarteriyel bileşkeden sinotubüler bileşkeye uzanarak sol ventrikül fizyolojik pompa işlevi için optimal yapıyı oluşturur. Aort kapak kompleksi, anatomik ve fizyolojik bir kavşak yapı şeklindedir. Bu araştırmada, aort kapak kompleksinin görüntüleme verileri kullanılarak, kardiyak cerrahiye uyarlanabilir geometrik aort kapak modeli oluşturulmaktadır. Gereç ve Yöntem: Aort kapağı, kök çapına bağıı olarak matematiksel olarak tanımlanabilen tutarlı bir forma sahiptir. Matematiksel yapıların geometrik modeli Bézier tekniği ile yani kurgulayıcı tarafından kontrol edilebilen bir eğri veya yüzey elde edilerek geliştirilmiştir. Öncelikle, modellenecek aort kapak dokusunun sınır Bézier eğrileri belirlenmiş, daha sonra yüzeyin bir çerçevesi ortaya çıkartılmışır. Bir sonraki aşamada bu çerçevede, interpolasyonlarla aort yaprakçıklarınnın modellenmesi gerçekleştirilmiştir. Bulgular: Üç boyutlu (3-B) bilgisayar destekli tasarım gösterimi Blender'da tamamlandıktan sonra, aort kapak kompleksi stereolitografik bir dokümana dönüştürülerek, aort kökü modeli polilaktik aşındırıcı lifler kullanılarak basıldı.

Sonuç: Üç boyutlu görüntüleme ile elde edilen kalp kapakçıklarının geometrik modellemesi, özel boyutlu protez kapakların üretiminde kullanılabilir. Kalp kapakçıklarının anatomik yapı özelliklerinin geometrik modelleme kullanılarak değerlendirilmesi geliştirilebilir ve diğer kalp kapakçıkları için de uyarlanabilir.

Anahtar Sözcükler: Aort kapak, aort kökü, geometrik modelleme, üç boyutlu baskı

\section{INTRODUCTION}

Aortic root morphology presents a complex junctional structure extending from the ventriculoarterial line to sinotubular line consisting of three Valsalva sinuses and cusps to achieve a pro- per physiological pump function of the left ventricle (1-4). The surgical treatment modalities of aortic valve diseases are either the repair or replacement of the aortic valve with a prosthesis. In recent years, aortic valve repair, rather than aortic valve replacement has gained popularity in the treatment of aortic root

Sorumlu Yazar/Corresponding Author: Nilgün BOZBUĞA E-mail: nilgun.bozbuga@istanbul.edu.tr

Submitted/Başvuru: 24.12.2021 • Revision Requested/Revizyon Talebi: 11.01.2022 • Last Revision Received/Son Revizyon: 14.01.2022 • Accepted/Kabul: 18.01.2022 • Published Online/Online Yayın: 03.02.2022 
pathology because of better hemodynamics and fewer presenting complications $(1,5-7)$.

There is still controversy about the best treatment for patients suffering from an aneurysmal dilatation of the ascending aorta concomitant with aortic valve insufficiency (8). Satisfactory results have been reported with the valve-preserving aortic replacement for patients whose aortic regurgitation is caused by an aortic root dilatation. Reconstructive techniques are comparable to the gold standard composite prosthetic graft replacement. For aortic valve disease, aortic valve replacement (AVR) is the gold standard for surgical therapy. Bioprosthetic implantation in elderly and fertility aged women is preferred due to a shorter life expectancy that does not require anticoagulation after AVR.

However, hemodynamic performance of prosthetic valves is not yet comparable to that of native aortic valves, because of limited durability. The current strategies used to create such valves are decellularized human donor tissue for tissue engineering (9). The creation of living-tissue engineered heart valves could be the solution for complications arising from prosthetic heart valves.

Tissue engineering and approximation to the modeling of aortic valve is particularly important for the reasons mentioned above. There are some models for approximation that utilize the finite element method $(10,11)$. Weber at al. (12) studied aortic leaflets design using tissue-engineering protocols. The design process is divided into several sub-stages: such as data collection, developments of ideas, concept, and suitable software. Apart from these, the process is expected to be short and effective both in the design phase and in the software. Previous works generally uses the mesh method from data.

In this study researchers presented the Bézier technique which is central in computer-aided geometric design and a special case of splines. Splines use control points and nodes, so more data is needed. However, in the Bézier section only control points are needed. Although this reduces control over the desired shape, it enables operations to be done faster. For this reason, this study chose the Bézier technique.

\section{METHOD}

A geometrical model of the aortic root was developed using computed tomography data of the heart. The aortic valve has a consistent shape with varying size, which is mathematically related to the root diameter. In future studies addressing aortic valve replacement, an anatomical approach using a customized geometric model of the aortic root will be used instead of replacing the defective valve with a standard artificial prosthesis. The advantage of producing a customized prosthetic valve using this method is that it reflects the unique geometric properties of the aortic valve better and the torsion and degeneration complications would be significantly reduced due to supporting the elastic structure of surgical annulus.

\section{Geometric Modeling Elements}

Geometric modeling is an extremely useful interdisciplinary subject with a wide range of applications such as engineering and medicine. Some scientists approach this subject mathematically (means here differential equation type) while others approach it geometrically. The Bézier technique is one of the main tools of computer-aided geometric design and a special case of splines. This technique is used for a user-controlled curve and surface. Primarily in this study, the boundary Bézier curves of the aortic valve tissue to be modeled are determined and thus a boundary of the surface is revealed. Then, a rational Bézier interpolation is performed in between on the boundary curves to form the desired aortic valve pattern. One of the most important issues is that the model depends entirely on the patient's data.

Definition 1. In general, a Bézier curve is a combination of three dimensional (3-D) real space points (control points) and Bernstein polynomials:

$$
B_{i}^{n}(t)=\sum_{i=0}^{n}\left(\begin{array}{l}
n \\
i
\end{array}\right)(1-t)^{n-i} t^{i}
$$

and

$$
\boldsymbol{\beta}(\mathrm{t})=\mathrm{B}_{\mathrm{i}}^{\mathrm{n}}(\mathrm{t}) \mathbf{P}_{\mathrm{i}}
$$

is a representation of a Bézier curve where $\mathbf{P}_{\mathrm{i}}$ are control points. Note that all expressions share the same index, i.e., the points belong to the sum symbol. One of the characteristics of these curves is that they can be designed completely as desired. In addition, the created Bézier curve passes through the first and last control points where it is defined. Thus, it has a convex structure (13).

Definition 2. A rational Bézier curve $\boldsymbol{\gamma}(\mathrm{t})$ is defined as: given $(n+1)$ points and related weights $\mathrm{q}_{j}$;

$$
\boldsymbol{\gamma}(\mathrm{t})=\frac{\sum_{j=0}^{n} B_{j}^{n}(t) q_{j} P_{j}}{\sum_{j=0}^{n} B_{j}^{n}(t) q_{j}}
$$

where $B_{j}^{n}$ are $n$th order Bernstein polynomials, (13). Here, the weight is a scalar number to affect the shape of Bézier curve $\gamma(\mathrm{t})$.

Definition 3. A rational Bézier surface patch $\alpha(u, v)$ is defined as: given $(m+1) \times(n+1)$ points and related weights

$$
\boldsymbol{\alpha}(\mathrm{u}, \mathrm{v})=\frac{\sum_{\mathrm{i}=0}^{\mathrm{m}} \sum_{\mathrm{j}=0}^{\mathrm{n}} \mathrm{B}_{\mathrm{i}}^{\mathrm{m}}(\mathrm{u}) \mathrm{B}_{\mathrm{j}}^{\mathrm{n}}(\mathrm{v}) \mathrm{q}_{\mathrm{ij}} \mathbf{P}_{\mathrm{ij}}}{\sum_{\mathrm{i}=0}^{\mathrm{m}} \sum_{\mathrm{j}=0}^{\mathrm{n}} \mathrm{B}_{\mathrm{i}}^{\mathrm{m}}(\mathrm{u}) \mathrm{B}_{\mathrm{j}}^{\mathrm{n}}(\mathrm{v}) \mathrm{q}_{\mathrm{ij}}}
$$

where $\mathbf{P}_{\mathrm{ij}}$ and $\mathrm{q}_{\mathrm{ij}}$ are control points and their correponding weights, respectively, (13).

\section{RESULTS}

In the first stage of the design, control circles were discussed instead of control points for defining the aortic vascular pathway:

$\varsigma_{0}:=\left[\begin{array}{lll}2 \cos t & 2 \sin t & 2\end{array}\right], \varsigma_{1}:=\left[\begin{array}{lll}4 \cos t & 4 \sin t & 4\end{array}\right], \varsigma_{2}:=\left[\begin{array}{lll}2 \cos t & 2 \sin t & 7\end{array}\right]$

Therefore, $z$-axis is vertical element for geometry. Interpolating control curves, we have a tube-type surface as follow for the geometric model of the sinotubular surface: 


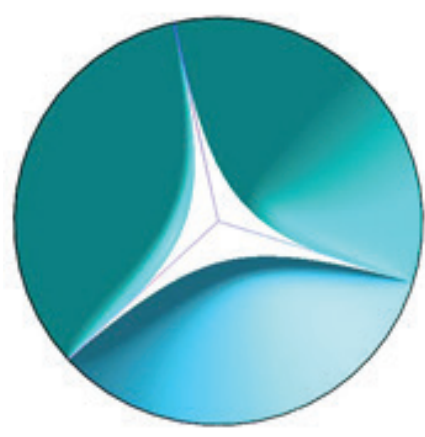

$w=2$

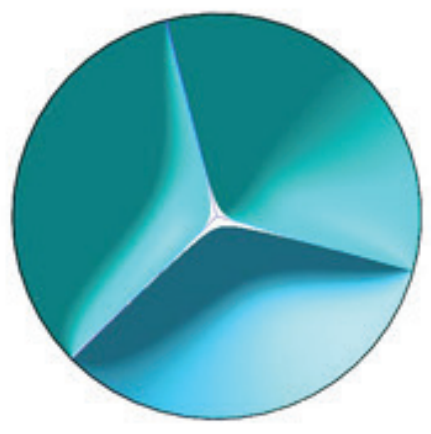

$w=20$

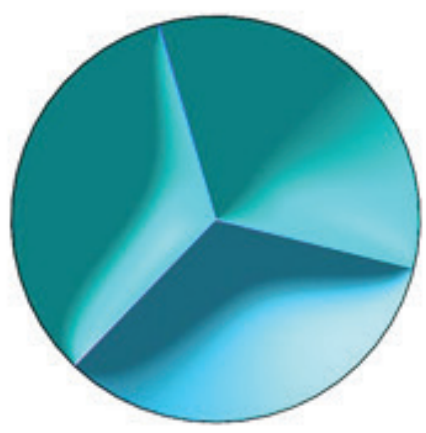

$w=200$

Figure 2: Different weight to construct the aortic valve types: Left to right the weights are 2, 20, 200.

$$
\mathbf{X}(u, t)=\sum_{i=0}^{2}\left(\begin{array}{l}
2 \\
i
\end{array}\right)(1-u)^{2-i} u^{i} c_{i}
$$

Here, the position and number of circles can be varied as desired. This allows the formation of individual models. Note that $c_{1}$ is not on the surface.

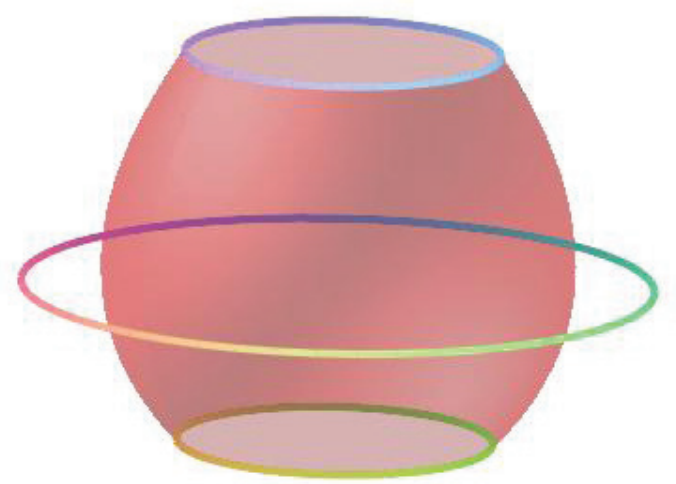

Figure 1: The aortic vascular pathway with its control circles

The model discussed was made with minimum geometric elements to create a standard frame. Moreover, a scale of elements of the geometric model can be easily adapted according to data.

In the design of aortic valves, start by taking the circle of the stent in the widest part of the vessel geometry $(u=1 / 2)$, in which the geometry of the three-valve sheets was formed. For this purpose, a 120-degree circle arc, which is 1 in 3 of the 360-degree frame, was taken as a control curve. Then, another control curve was obtained by rotating 90 degrees downward about the axis of the secant line segment whose endpoints are the same as those formed by the combination of these endpoints. Nevertheless, the mid-control point generally differs from the former curve since the sectional curve of the surface of the aortic valve is of various types.

The last control curve, which is also considered a Bézier curve, takes the endpoints of these curves and the center of the big circle as control points. So, a rational Bézier surface patch is obtained. When this surface is reproduced at 120 degrees of rotation around axis (generated by points which are center of horizontal sectional circles) of tube-type surface, all the aortic valves are obtained to form the entire geometry.

\section{APPLICATION}

The equations of the above construction are given as follows: Let first define the control curves as follows,

$$
\begin{aligned}
& \mathbf{k}_{0}=(1-w)^{2}\left[\begin{array}{lll}
3 & 0 & \frac{17}{4}
\end{array}\right]+2 w(1-w)\left[\begin{array}{lll}
0 & 0 & 0
\end{array}\right]+w^{2}\left[\begin{array}{lll}
-\frac{3}{2} & \left(\frac{3}{2}\right) \sqrt{3} & \frac{17}{4}
\end{array}\right], \\
& \mathbf{k}_{1}=\frac{1}{1+400 w-400 w^{2}}\left((1-w)^{2}\left[\begin{array}{lll}
3 & 0 & \frac{17}{4}
\end{array}\right]\right. \\
& \left.+400 w(1-w)\left[\begin{array}{lll}
0 & 0 & \frac{17}{4}
\end{array}\right]+w^{2}\left[\begin{array}{lll}
-\frac{3}{2} & \left(\frac{3}{2}\right) \sqrt{3} & \frac{17}{4}
\end{array}\right]\right), \\
& \mathbf{k}_{2}=\left[\begin{array}{ll}
3 \cos \frac{2 w \pi}{3} 3 \sin \frac{2 w \pi}{3} & 17 / 4
\end{array}\right]
\end{aligned}
$$

where $w \in[0,1]$ and $\mathbf{k}_{i}$ are the control curves of the geometry representing the aortic valve. Now the leaflets of the aortic valve can be constructed. Interpolation of these control curves gives the geometry of leaflet of the aortic valve

$$
\mathbf{s}_{1}=\sum_{i=0}^{2}\left(\begin{array}{l}
2 \\
i
\end{array}\right)(1-\mu)^{2-i} \mu^{i} \mathbf{k}_{i}
$$

The other leaflets can be represented by matrix multiplication so a rotation around the vertical axis $z$ :

$$
\begin{aligned}
& \mathbf{s}_{2}=\mathbf{s}_{1} \cdot\left(\begin{array}{ccc}
\cos 2 \pi / 3 & \sin 2 \pi / 3 & 0 \\
-\sin 2 \pi / 3 & \cos 2 \pi / 3 & 0 \\
0 & 0 & 1
\end{array}\right), \\
& \mathbf{s}_{3}=\mathbf{s}_{1} \cdot\left(\begin{array}{ccc}
\cos 4 \pi / 3 & \sin 4 \pi / 3 & 0 \\
-\sin 4 \pi / 3 & \cos 4 \pi / 3 & 0 \\
0 & 0 & 1
\end{array}\right)
\end{aligned}
$$

where $\mu \in[0,1]$ and $\mathbf{s}_{i}$ are patches showing the leaflets. The weight value in the example was considered 400 in order for the aortic valves to merge sufficiently in the center. As the weight value increases, the entire geometry of the aortic valve nearly closes, especially at the midpoint (Figure 2).

As a result, the combined model of aortic valve complex and sinotubular surface from this mathematical construction can be given (Figure 3 ). 


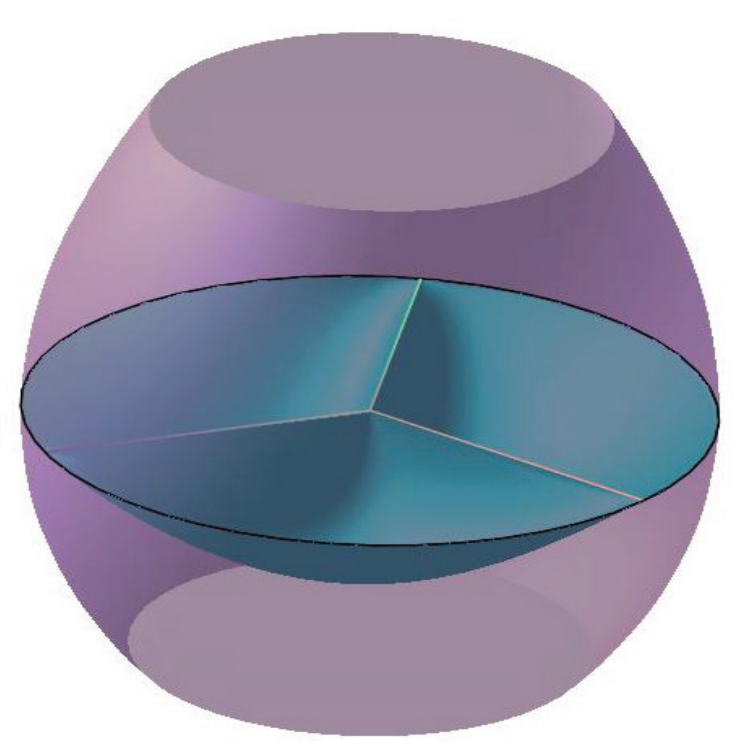

Figure 3: The aortic valve complex

3-dimensional printing: After the 3-D computer aided design is completed in Blender, the aortic valve is exported as a stereolithographic (STL) document. This is the necessary for fast prototyping purposes. The STL document altered by Blender was cut in the SIMPLIFY3D programming (V: 4.1.2) for 3-D printing (Figure 4).

\section{DISCUSSION}

The anatomic approach to the geometry of the aortic valve complex was based largely on autopsy and cadaveric studies (2). The aortic root is the anatomic and functional unit that constitutes the main portion of the left ventricular outflow tract; it includes the aortic valve leaflets, the aortic annulus surrounding the valvular orifice, the Valsalva sinuses containing both coronary ostia and the proximal ascending aorta. Aortic root pathologies requiring surgical intervention have high incidence of mortality and morbidity. On this basis, computational models are increasingly used to restore aortic root biomechanics.
Complete experimental measurements with quantification of tissue strains and stresses, as well as of blood fluid dynamics have been documented $(14,15)$.

Aortic valve replacement is the treatment of choice for aortic valve disease, and despite the progress of the design and construction of artificial prosthetic valves, hemodynamic performance is not yet comparable to that of native aortic valves. There are some limitations of durability in consequence of degeneration with bioprosthetic valves and disadvantages of anticoagulation and risk of endocarditis with mechanical prosthetic valves (16). Bioprosthetic valves are used increasingly because of the complications with inevitable postoperative anticoagulation of mechanical valves in the elderly. Bioprosthetic valves are also preferred by young women of childbearing age for avoiding embryopathic and teratogenethic effects of warfarin. Replacement with a bioprosthesis can cause accelerated degeneration in young patients because of calcium metabolism. Immune reaction and calcium turn-over may play a role in the degeneration of an implanted bioprosthesis, especially in younger patients during their growth period. Pediatric patients with valve disease are faced with a lifelong risk of prosthetic valve-related morbidity and up to $50 \%$ reduction in life expectancy. Under these lifethreatening circumstances, the necessity for a new prosthetic valve solution continues.

The ideal valve prosthesis provides nonthrombogenic long-term durability so the potential solution may be a tissue engineered heart valves. Techniques for tissue engineered heart valve development have included in vitro fabrication, cell seeding, conditioning, and secondary implantation more recently, in situ scaffold implantation and subsequent autologous tissue replacement (9).

\section{CONCLUSION}

The geometric model from three-dimensional imaging of the heart valves developed here can be adapted for individual customized aortic valves. The analysis of geometrical modeling concluded that the 3-D printing of the aortic valve for surgical valve-prosthesis replacement treatment and surgical treatment of the various aortic root pathologies depends on the anatomic and geometric design of the aortic root.

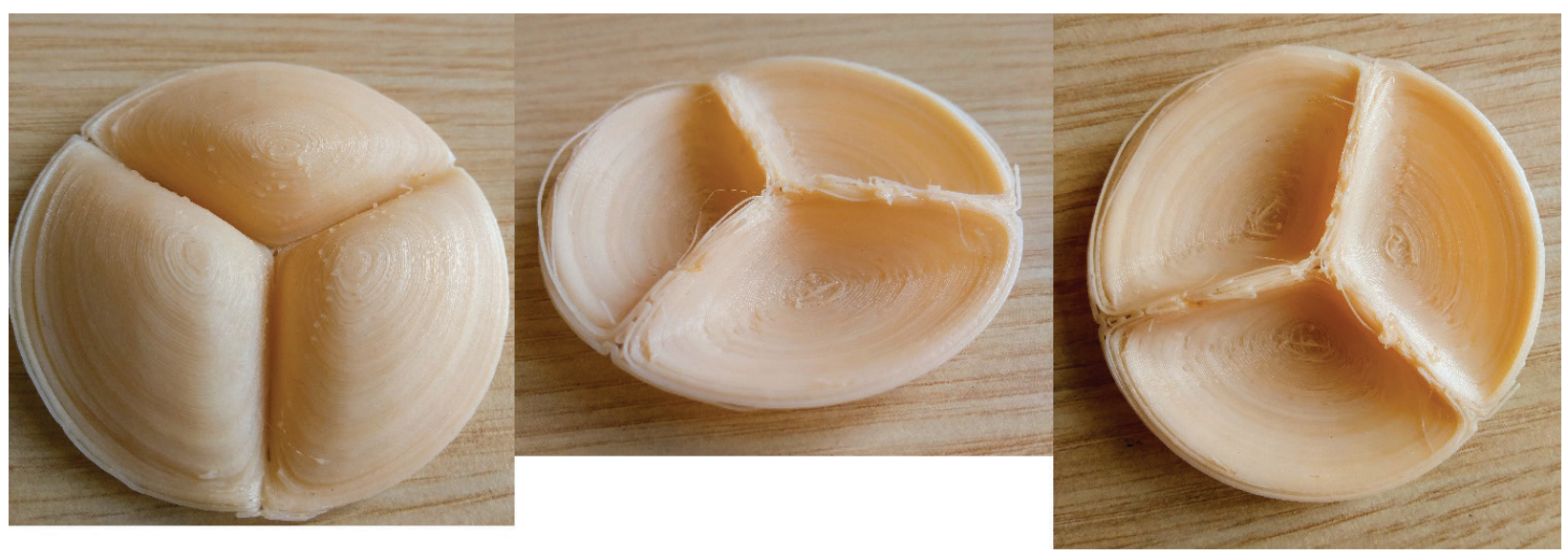

Figure 4: 3-D printing of aortic valve model made of soft filament 
The researchers of this study think that geometric modeling of tissue will become more important in the coming years. This special technique for the production of a customized aortic valve developed here could be adapted for other heart valves, so that three-dimensional printing usage could be expanded. There is no doubt that the medical effects of this study will become common and universal. The aortic root morphology of particular interest in this study has a complex geometry. Especially in the design phase of leaflets, the design method chosen was discussed extensively. Geometric modeling can provide detailed information on aortic root biomechanics and an understanding of the aortic valve complex pathophysiology. Other techniques can of course be found for modeling this type of geometry. Evaluation of the anatomical structure features of heart valves using geometrical modeling could be developed and adapted for other heart valves.

However, we chose the method that created the most effective model for both the user and the software. As a continuation of this study, an evaluation will be done on how biocompatible material behaves against physical influences by making a model out of this material.

Peer Review: Externally peer-reviewed.

Author Contributions: Conception/Design of Study- N.B.,F.T.; Data Acquisition- N.B.,F.T.; Data Analysis/Interpretation- N.B.,F.T.; Drafting Manuscript- N.B.,F.T.; Critical Revision of Manuscript- N.B.,F.T.; Final Approval and Accountability- N.B.,F.T.

Conflict of Interest: Authors declared no conflict of interest.

Financial Disclosure: Authors declared no financial support.

Hakem Değerlendirmesi: Dış bağımsız.

Yazar Katkıları: N.B.,F.T.; Veri Toplama- N.B.,F.T.; Veri Analizi/YorumlamaN.B.,F.T.; Yazı Taslağı- N.B.,F.T.; İçeriğin Eleştirel İncelemesi- N.B.,F.T.; Son Onay ve Sorumluluk- N.B.,F.T.

Çıkar Çatışması: Yazarlar çıkar çatışması beyan etmemişlerdir

Finansal Destek: Yazarlar finansal destek beyan etmemişlerdir.

\section{REFERENCES}

1. Bozbuğa N, Erentuğ V, Kırali K, Akıncı E, Işık Ö, Yakut C. Midterm results of aortic valve repair with the pericardial cusp extension technique in rheumatic valve disease. Ann Thorac Surg 2004;77(4):1272-6.

2. Uğurlucan $M$, Beyaz MO, Öztaş MD, Özturk $A$, Şahinoğlu K, Alpagut $\mathrm{U}$, Bozbuğa N. The geometrical modeling of aortic root complex. Heart Views 2019;20(1):6-10.

3. Flamini V, DeAnda A, Griffith BE. Immersed boundary-finite element model of fluid-structure interaction in the aortic root. Theor Comput Fluid Dyn 2016;30(1):139-64.
4. Qiao A, Pan Y, Dong N. Modeling study of aortic root for Ross procedure: a structural finite element analysis. J Heart Valve Dis 2014;23(6):683-7.

5. Bozbuğa N, Erentuğ V, Erdoğan HB, Kırali K, Ardal H, Taş S, Akıncı $E$, Yakut C. Surgical treatment of aortic abscess and fistula: Reconstruction of the aortic annulus with pericardium in complex aortic root infection. Tex Heart Inst J 2004;31(4):382-6.

6. Bozbuğa N, Güler M, Kırali K, Akıncı E, Işık Ö, Yakut C. The durability of valve reconstruction in rheumatic mitral and aortic valves: controvertial in the best treatment for double valve disease. Journal of Cardiovascular Forum on Line 2003;1(2):0037-46.

7. Bozbuğa N, Mansuroğlu D, Işık Ö, İpek G, Eren E, Gürbüz A, Balkanay M, Dağlar B, Yakut C. Aortic reconstructions. European Journal for Cardiac Interventions (Cor Europeum) 1996;5(4):143-5.

8. Al-Atassi T, Toeg HD, Jafar R, Sohmer B, Labrosse M, Boodhwani M. Impact of aortic annular geometry on aortic valve insufficiency: Insights from a preclinical, ex vivo, porcine model. The Journal of Thoracic and Cardiovascular Surgery 2015;150(3):656-64. e1. doi: 10.1016/j.jtcvs.2015.06.060.

9. Coyan GN, D'Amore A, Matsumura Y, Pedersen DD, Samul K. Luketich SK, Shanov V, Katz WE, David TE, Wagner WR, Badhwar $V$. In vivo functional assessment of a novel degradable metal and elastomeric scaffold-based tissue engineered heart valve. The JTCVS 2018;157(5):1809-16.

10. Driessen, NJ, Boerboom RA, Huyghe JM, Bouten CV, Baaijens F. Computational analyses of mechanically induced collagen fiber remodeling in the aortic heart valve. J Biomech Eng 2003;125(4):549-57.

11. Ovcharenko EA, Klyshnikov KU, Vlad AR, Sizova IN, Kokov AN, Nushtaev DV, Yuzhalin AE, Zhuravleva IU. Computer-aided design of the human aortic root. Comput Biol Med 2014;54:10915.

12. Weber M, Heta E, Moreira R, Gesche VN, Schermer T, Frese J, Jockenhoevel S, Mela P.Tissue-engineered fibrin-based heart valve with a tubular leaflet design. Tissue Eng Part C Methods. 2014;20(4):265-75. doi: 10.1089/ten.TEC.2013.0258.

13. Farin, G. Curves and surfaces for computer-aided geometric design: a practical guide. Elsevier, 2014.

14. Pan Y, Qiao A, Dong N. Fluid-structure interaction simulation of aortic valve closure with various sinotubular junction and sinus diameters. Ann Biomed Eng 2015;43(6):1363-9

15. Crooke PS, Beavan LA, Griffin CD, Mazzitelli D, Rankin JS. A geometric model of the normal human aortic root and design of a fully anatomic aortic root graft. Innovations (Phila). 2015;10(1):5762.

16. Kuana YH, Kabinejadiana F, Nguyenb VT, Yoganathanc AP, Leoa $\mathrm{HL}$. Comparison of hinge microflow fields of bileaflet mechanical heart valves implanted in different sinus shape and downstream geometry. COMPUT metod biome engin 18(16):1785-96, 2015 